\title{
Testing the Environmental Kuznets Curve Hypotheses in Chinese Provinces: A Nexus between Regional Government Expenditures and Environmental Quality
}

\author{
Ayoub Zeraibi ${ }^{1, *}$, Daniel Balsalobre-Lorente ${ }^{2}\left(\mathbb{D}\right.$ and Khurram Shehzad ${ }^{3}$ \\ 1 School of Economics and Finance, Xi'an Jiaotong University, Xi'an 710049, China \\ 2 Department of Political Economy and Public Finance, Economic and Business Statistics and Economic Policy, \\ University of Castilla-La Mancha, 13001 Ciudad Real, Spain; Daniel.Balsalobre@uclm.es \\ 3 School of Economics and Management, Southeast University, Nanjing 211189, China; \\ khurramscholar64@hotmail.com or 233189917@seu.edu.cn \\ * Correspondence: Azeraibi@stu.xjtu.edu.cn
}

check for updates

Citation: Zeraibi, A.;

Balsalobre-Lorente, D.; Shehzad, K. Testing the Environmental Kuznets Curve Hypotheses in Chinese Provinces: A Nexus between Regional Government Expenditures and Environmental Quality. Int. J. Environ. Res. Public Health 2021, 18, 9667. https://doi.org/10.3390/ ijerph18189667

Academic Editors: Elena Rada, Maria Cristina Collivignarelli and Paul B. Tchounwou

Received: 6 July 2021

Accepted: 7 September 2021

Published: 14 September 2021

Publisher's Note: MDPI stays neutral with regard to jurisdictional claims in published maps and institutional affiliations.

Copyright: (c) 2021 by the authors. Licensee MDPI, Basel, Switzerland. This article is an open access article distributed under the terms and conditions of the Creative Commons Attribution (CC BY) license (https:/ / creativecommons.org/licenses/by/ $4.0 /)$.

\begin{abstract}
With rapid economic growth, the Chinese government expenditures at various levels have increased adequately. At the same time, the environmental quality in China has deteriorated significantly. In this study, provincial-level data for 31 Chinese provinces during 2007-2017 are used to investigate the impacts of government expenditure on the emissions of three specific measures of environmental degradation. The main objective of this study is to examine the influence of government expenditures, economic growth per capita, environment protection expenditure, and added second-sector value on environmental quality by measuring sulfur dioxide $\left(\mathrm{SO}_{2}\right)$, chemical oxygen demand (COD), and ammonia nitrogen emissions (AN). Moreover, the study applied the generalized method of moments (GMM) and the fully modified least square (FMOLS) to estimate the co-integration relationship among the underlying factors. The results demonstrate a significant direct effect of government expenditure on improving environmental quality overall in the Chinese provinces, which increases with the level of economic growth. However, the results also confirmed the inverted $\mathrm{N}$-shaped relationship between the pollution factor and economic growth per capita. Our key findings lead toward the manifestation and emphasis of the importance of appropriate policies for restoring government expenditure and, at the same time, strengthening the relationship between the industrial sector and environmental policy standards. Significantly, governments in developing countries should allocate larger budgets for environmental projects in their fiscal reforms for the sake of moving to greener and more inclusive economies with low-carbon activities.
\end{abstract}

Keywords: China; government spending; environment's sustainability; N-shaped; orthogonal-GMM

\section{Introduction}

Due to economic growth, environmental pollution and protection have grown increasingly severe in many developing countries, particularly China. As the world's secondlargest economy, the Chinese government has invested much in environmental regulation and protection, 37 trillion USD. Moreover, China has invested 41 trillion USD in their 18 provinces for the treatment of water pollution. In addition, China is introducing energyefficient and environmentally friendly products to overcome environmental pollution [1]. However, China ranked 14th in environmental pollution throughout the world [2]. Hence, air pollution has become one of the most pressing issues affecting people's health and China's economic development in the new millennium [3,4]. The problem of environmental pollution in developing countries is increasingly diminished as economic growth takes hold in countries such as China. This process is known as the composition effect $[5,6]$. In recent years, various studies have examined the effect that government expenditure and financial development have on environmental quality in regions such as the Middle 
East [7]. The concept of the scale effect comes about through how government spending, which is considered an income effect, increases when environmental pollution occurs due to economic growth.

Having one of the world's largest economies, the Chinese government has made efforts to reduce environmental pollution caused by rapid economic growth by imposing regulations limiting the amount of pollution caused by commercial industries. Environmental quality can be improved by utilizing human capital more than physical capital since it is more environmentally friendly, increasing government spending. Some studies mainly focus on economic and social determinants such as GDP per capita and urbanization [8], while other studies examine how government policies influence environmental pollution [9].

Some authors $[9,10]$ have investigated how $\mathrm{CO}_{2}$ emissions are influenced by environmental innovation and the effects of decentralization on environmental quality in China. Such studies, amongst others, give evidence of how government expenditure is a substantial factor [7]. In Northern Africa and the Middle East, environmental quality is affected by public expenditure, as shown in [9].

Using data from 77 countries, the study by [7] determined that $\mathrm{CO}_{2}$ and $\mathrm{SO}_{2}$ emissions have a negative effect on government expenditure. Similar to [11], they argued that as the economy grows, environmental pollution also increases, increasing government spending, which is namely, the scale effect. In contrast, the composition effect utilizes human capital over physical capital, which can be harmful to the environment. Furthermore, this can lead to what is known as the technique effect, whereby government expenditure increases due to the increase in labor productivity.

Government expenditure can also increase through the income effect; as more people obtain a higher income, their care for better environmental quality is also enhanced. The study by $[12,13]$ shows the impact that government expenditure has on environmental quality, and it can differ according to some influential determinants or pollutants.

In this study, three pollutants are used in the investigation to determine the effect that government spending has on environmental quality in China. This study uses three main determinants for the investigation: $\mathrm{SO}_{2}, \mathrm{COD}$ release, and $\mathrm{AN}$ emissions. These pollutants are used because they have different characteristics and can provide a detailed environmental quality analysis. They have been under the government's control for longer due to their harm to ecosystems and the environment [13]. $\mathrm{SO}_{2}$ emissions have contributed to the pollution problem in China in recent years. This is also true for COD release that indicates water pollution due to coal combustion [14]. China planned and managed to significantly reduce COD release by $8 \%$ within a period of six months through the 12 th Five-Year Plan.

Figure $1 \mathrm{a}-\mathrm{d}$, indicates the three pollutants in the 31 provinces of China $\left(\mathrm{SO}_{2}, \mathrm{COD}\right.$ release, and AN emissions levels) and regional economic growth per capita. We observed in Figure 1 that the provinces with a high level of economic growth are also offset by a high level of pollution, except for the provinces of Beijing and Shanghai, whose local governments are working to raise the volume of spending on the environment and improve its quality [15].

We also note that dioxide emissions have increased in the northwestern and northeastern regions, which are areas rich in mining and metallurgical industry [16]. However, these regions have a low growth rate because the region is for the extraction of raw materials and is far from the coast and major commercial places in China. Hence, the extraction of raw materials contributes to rising levels of pollution. 

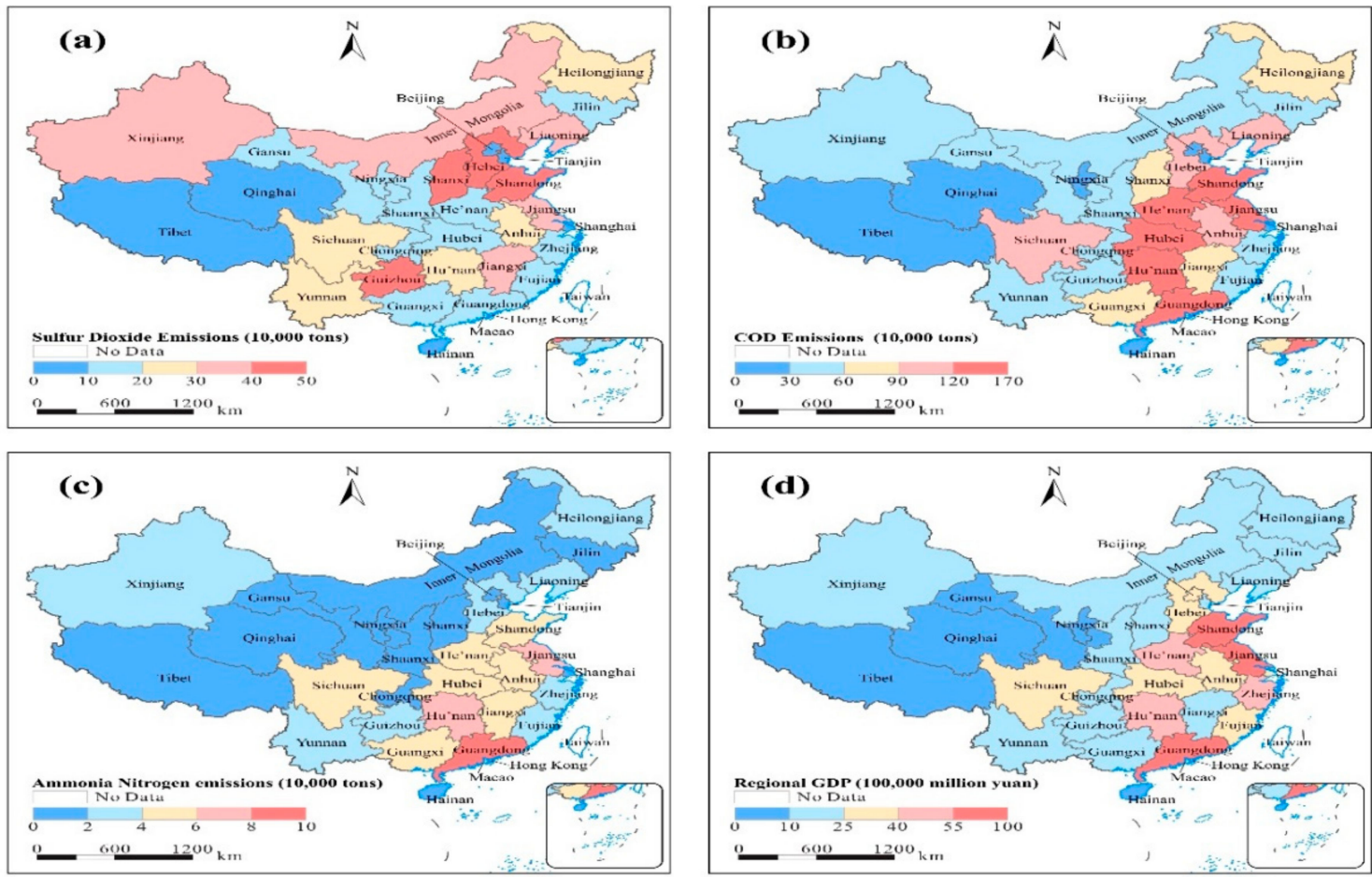

Figure 1. (a) Pollutants sulfur dioxide $\left(\mathrm{SO}_{2}\right)$, (b) chemical oxygen demand (COD), and (c) ammonia nitrogen emissions (AN), and (d) provincial economic growth per capital (GDPP).

In Figure 2, the graph shows the provinces of China that have government spending to protect the local environment. The figure shows that there are provinces that are interested in preserving the environment by increasing the volume of government expenditures on the environment, such as Beijing, Jiangsu, and Guangdong, similar to the Hubei region, which is famous for its heavy industries with high pollution. This study's essential contribution is two-fold. First, the current study is one of the few that analyze the relationship between sources of pollution and economic growth in the context of the impact of government expenditure and environmental quality under an N-shaped EKC scheme. Second, this study measures the effects of three sources of emissions-COD release, $\mathrm{SO}_{2}$, AN emissions-on economic growth in various provinces of China [17]. This study also explores the total local government expenditure contribution, taking into account the local government spending to protect the environment in Chinese provinces. Previous studies have used carbon emissions to measure environmental pollution. However, only carbon emissions alone cannot characterize environmental pollution in its entirety [18]. Hence, this investigation employed three proxies, $\mathrm{SO}_{2}, \mathrm{COD}$, and $\mathrm{AN}$ emissions, which measure maximum environmental pollution. Particularly, COD release is a significant measure of water pollution, which is used by various studies. Consequently, the current study allows us to measure the extent and seriousness of the Chinese government's contribution towards preserving the environment in its general form on the Chinese state as a whole and also in part, represented by the Chinese provinces [19]. This is in contrast to previous studies, which relied on short- and long-term analysis in their approach [20]. The remainder of this paper is developed as follows: The relevant literature review is conducted in Section 2. The data and methodology are introduced in Section 3. The estimation results and analyses are described in Section 4. The conclusion appears in the last section, which also provides several policy recommendations. 


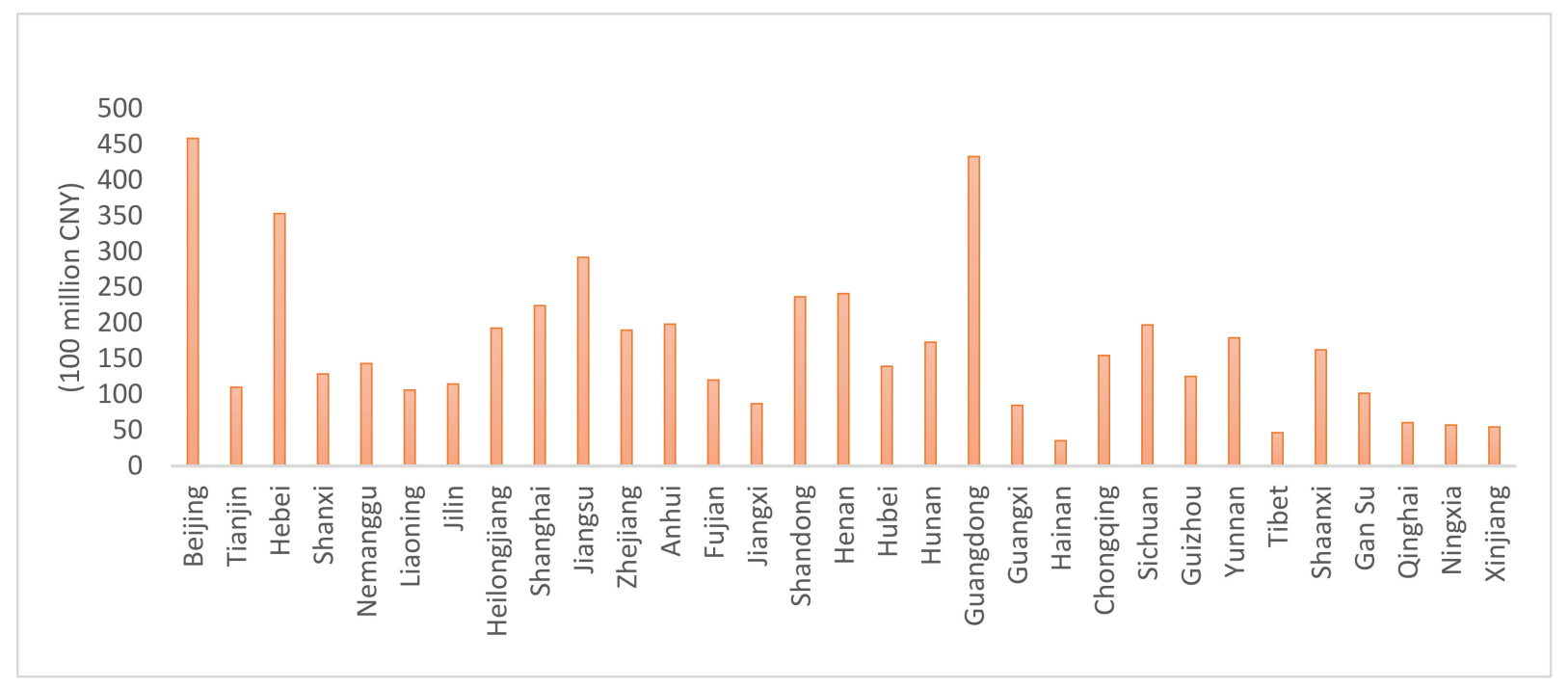

Figure 2. The local Chinese provincial fiscal expenditure on environmental protection (100 million CNY) in 2017.

\section{Literature Review}

To date, there have been several studies on the factors that influence environmental pollution. Various studies, such as the Kuznets environmental curve and the hypothesis of a pollution refuge, are based on traditional theories explaining the relationship between environmental quality and economic growth [21,22]. Several previous studies have investigated the relationship between government expenditure and environmental quality in China. However, the results diverged significantly. The use, and then the excessive use and mitigation of pollution, and climate change, make up a broad field of empirical research in the literature pertaining to economic growth and the environment [23]. Moreover, the authors explored the linkage between the government expenditure and pollution factors in China by using the GMM approach for the period 2002-2014; the study result indicates the existence of the EKC hypothesis with an inverted U-shape and N-shape. A similar study by [24] analyzed the relationship between $\mathrm{SO}_{2}$ emissions and government expenditures in the case of China for the period 2008-2013, which applied spatial competition; the result confirmed a positive spatial correlation of $\mathrm{SO}_{2}$ emissions among provinces in China. It also confirmed the existence of the N-shaped EKC hypothesis. The examination also indicated a positive association between the second-sector value and $\mathrm{SO}_{2}$ emissions.

Similarly, [25] clarified the relationship between environmental quality and economic growth in the context of the EKC hypothesis, and used $\mathrm{SO}_{2}$, emissions together with COD release. The investigation result indicated a relationship between economic growth per capita and $\mathrm{SO}_{2}$ emissions and COD release in the period 1998-2016, which also confirmed the pollution halo hypothesis. In the same context, [26] examined the association relationship between noise pollution and economic growth in 111 Chinese cities by using the GMM approach to test the existence of the N-shaped EKC hypothesis; the result confirmed the invert $\mathrm{N}$-shape between economic growth per capita and noise pollution.

In contrast, [27] investigating the linkage between the fiscal expenditure and $\mathrm{SO}_{2}$ emissions as an environmental quality proxy in China at the provincial level, in the period 1995 to 2015, applied the GMM approach to determine the role of provincial and regional economic growth on financial autonomy in China [28]. The results indicate an inverted-U shape between economic growth per capita and fiscal expenditure [29]. The study also shows a positive relationship between economic growth and fiscal expenditure, together with an inverted U-shaped and $\mathrm{N}$-shaped relationship between the $\mathrm{SO}_{2}$ emissions and economic growth in China [30]. Moreover, the study also indicates that the second-sector value adds positively to affect environmental degradation. In contrast, explored the relationship between the local government expenditure and the $\mathrm{SO}_{2}$ emission in 31 of China's provinces from 2007 to 2016. The econometric approach reveals a negative relationship between $\mathrm{SO}_{2}$ 
emission and local government expenditure. In addition, the study indicates the existence of an inverted U-shaped EKC hypothesis in a few provinces and not in others [31]. The relationship between the fiscal government and environmental quality in the top ten Asian carbon emissions for the period 1981-2018 was analyzed in [31]; the result shows that positive shock in government expenditure will worsen environmental quality in Malaysia, UAE, Thailand, Indonesia, Turkey, Iran, India, and China, but improve it in Japan. In the same contexte, [32] applied the GMM method to examine the relationship between $\mathrm{SO}_{2}$ emissions, $\mathrm{COD}$ release, and $\mathrm{AN}$ emission pollution factors and local and provincial economic growth in 31 provinces in China for the period 2004 to 2016. The study's result indicates the positive relationship between economic growth and the three pollutions factors. This corresponds to [33], who clarified the linkage between government expenditure as fiscal policy proxy and environmental quality in China for the period 1980-2016. The empirical result indicates the positive relationship between government expenditure and environmental degradation with the existence of EKC hypothesis, both in the long and short term. The analysis by [34] analyzed the linkage between $\mathrm{SO} 2$ emission and regional economic growth in 29 provinces for the period 1998-2015. The empirical results indicated a positive relationship between the regional economic growth and the pollution factor the $\mathrm{SO} 2$ emission, validating the inverted-U and the N-shaped EKC hypothesis. Moreover, in the context of Pakistan [35], when investigating the nonlinear relationship between the role of fiscal policy on environmental quality, the empirical result shows the negative effect of fiscal policy instruments on the environmental quality in the long term, with the validation of the inverted U-shaped relationship for the period 1985 to 2016. However, the analysis by [36], when analyzing the effect of both fiscal expenditure and environmental expenditure on the environmental quality in the emerging economies for the period 1995 to 2016, indicated the positive effect of the environmental expenditure and environmental degradation and negative effect on the fiscal expenditure. Additionally, the empirical analysis by [37] clarified the nexus between public expenditure and environmental quality in 94 countries, which measured the environmental quality by the $\mathrm{SO}_{2}$ and $\mathrm{AN}$ emissions for the period 1970 to 2008. The study demonstrated the significant positive and direct effect of public expenditure on the environmental quality factor. The total effect was divided into direct and indirect effects, and both short- and long-term impacts were discussed. In this research, the environmental Kuznets curve (EKC) hypothesis model was used to examine the impact of government expenditure on pollutant emissions.

Thereafter, many researchers investigated the existence of an EKC hypothetical relationship between GDP per capita and certain pollutants [16,17]. However, the estimation results are still controversial [38]. Found evidence for the existence of an inverted Nshaped EKC hypothesis for COD release for all of China and Shanghai city. In addition, the existence of an inverted U-shaped EKC in the G20 group members was reported.

Additionally, [12] analyzed Chinese survey data and found that the relationship between $\mathrm{CO}_{2}$ emissions per capita and GDP per capita is N-shaped, suggesting there may not be a turning point for $\mathrm{CO}_{2}$ emissions in China. As many previous studies have used typical pollutants as the proxy of environmental quality, in this study, three representative pollutants $\mathrm{SO}_{2}$ emissions, $\mathrm{COD}$ release, $\mathrm{AN}$ emissions-are chosen for empirical estimations. These contrasting pollutants have various characteristics and therefore reflect the different aspects of China's environmental pollution. Consequently, examining these pollutants helps us understand the full story of environmental impacts related to government spending in China.

Despite several previous studies, the link between government expenditure and environmental quality in China has been rarely explored, and mainly only when using provincial data. As a result, this research analyzes panel data from 31 Chinese provinces to examine the link between government expenditure and $\mathrm{SO}_{2}$ emission, $\mathrm{COD}$ release, and AN emission pollutants; furthermore, the total effect of government expenditure is estimated. 


\section{Methodology and Data Description \\ 3.1. Methodology}

This study applies the generalized method of moments (GMM) methodology to determine provincial government expenditure's direct and indirect impacts. The study's econometric approach is the generalized method of moments (GMM) technique. The GMM approach is used to determine the direct and indirect impacts of provincial government. Since the goal of the research is to distinguish the direct and indirect effects of the proportion of government expenditure over GDP, the estimation method utilized in this research is a two-stage regression model. First, under the EKC framework, this study examines the impact of government expenditure on GDP per capita, applying both the GMM and data fixed effects methods. The GMM approach was introduced by [39] then developed by [40]. Previous studies have used this method to analyze the connection between GDP and pollutant emissions [41]. The results obtained from this research using the GMM method are used as the benchmark due to its efficiency in analyzing the data in different Chinese cities. Moreover, the first-difference GMM method can solve the endogeneity problem due to bilateral causality between GDP per capita and government spending [42].The impacts of government expenditure on pollutant emissions are estimated using the environmental Kuznets curve [43]. The EKC hypothesis explains an inverted N-shaped relationship between economic growth and environmental degradation; environmental pressure increases in the early stages of economic growth due to the increased release of pollutants and the extensive and intensive exploitation of natural resources associated with the greater use of production resources, and the adoption of certain production technologies for the growing economic activities, up to a certain level, as income rises [44,45]. After that, it decreases, probably because of the growing public awareness and concern about environmental degradation and the research and development activities being oriented more toward the concept of the green economy when GDPP at a high level. The third stage, which can return to the parallel relationship between economic growth and pollutants, implements the cube of economic growth.

Both the fully modified ordinary least square (FMOLS) and the generalized method of moments (GMM) approach are used in the empirical estimations. introduced the generalized method of moments (GMM), which was studied further by others [46]. Because it can eliminate any endogeneity bias, many previous studies have used the GMM method to estimate the relationship between GDPP and pollutant emissions. The results of the first-difference GMM technique are used as the benchmark in this study because individual differences may be eliminated [47]. It is reasonable to infer that there are significant differences between Chinese provinces, which the explanatory variables can highlight.

The following equation is used in the first step of estimating the direct effect of go share on GDP per capita:

$$
\left(\operatorname{LnGDPP} P_{i t}\right)=\mu_{i}+\delta_{t}+\alpha_{0}\left(\operatorname{LnGDPP} P_{i t}\right)+\beta_{1}\left(L n L G E_{i t}\right)+\beta_{3}\left(\operatorname{LnENV} E_{i t}\right)+\beta_{4}\left(\operatorname{LnLSSVA} A_{i t}\right)+\varepsilon_{i t}
$$

In Equation (1), $\ln$ is the logarithmic term for the province I's GDP per capita in year t. (1.) $G D P_{i t}$. In addition, a lag factor was introduced to the factor to account for the link between annual GDP per capita and pollutant emissions factors: $\mathrm{COD}$ release, $\mathrm{SO}_{2}$, and AN emissions [48]. The logarithmic terms of province government expenditure on the environmental and second-sector value added are given by the control variables ENVE and SSVA, respectively. The second equation examines the direct effect of go share on pollutant emissions, the same as Equation (1) estimates the government proportion on GDPP:

$$
\begin{gathered}
\left(L n \gamma_{i t}\right)=\theta_{i}+\sigma_{t}+\left(L n \gamma_{i t}\right)+ \\
\beta_{1}\left(L n G D P P_{i t}\right)+\beta_{2}\left(\operatorname{LnGDPP} P_{i t}\right)^{2}+\beta_{3}\left(L n G D P P_{i t}\right)^{3}+\beta_{4}\left(L n L G E_{i t}\right) \\
+\beta_{5}(\operatorname{LnENVE})+\beta_{6}\left(\operatorname{LnSSVA} A_{i t}\right)+\varepsilon_{i t}
\end{gathered}
$$

The $(\gamma)$ stands in different pollutant emissions per capita, such as $\mathrm{COD}$ release, $\mathrm{SO}_{2}$, and AN emissions; ENVE represents the local government environmental expenditure; SSVA represents the second-sector value added; moreover, the study variables are in logarithmic terms. According to the Equation (2), the direct and indirect effects can be calculated. Specifically, the direct effect is merely a constant number, such as the coefficients 
of $\beta 4$ in Equation (2), while the indirect effect is the product of the marginal effect of go share on GDPP and GDPP on pollutant emissions.

\subsection{Data Description}

This study used data from 31 Chinese provinces between 2007 and 2017. The selected panel data were used because of its larger sample size and capacity to efficiently handle heteroskedasticity across the cities efficiently. The data characteristics include the province's number $(\mathrm{N}=31)$, which is larger than the study period $(\mathrm{T}=20)$. Metropolitan regions produce the most pollutants; therefore, municipal statistics might offer a detailed picture of the environmental status. The Chinese government's interest in the environment and climate change has increased, which led it to allocate spending at the county level to protect the environment. The relationship between government expenditure and environmental quality are examined and investigated by introducing the second stage of the secondary industry value-added to the GDP per capita [49]. We used three variables chosen as the main variables; first, two wastewater pollutants: chemical oxygen demand emissions (COD) $(10,000$ tons) and ammonia nitrogen emissions (AN) (10,000 tons) in wastewater; second, the study tested the emission of gases and their impact on environmental degradation, sulfur dioxide emission $\left(\mathrm{SO}_{2}\right)(10,000$ tons) in waste gas was used as the variable.

We used the proportion of provincial government expenditure, provincial environmental expenditure, and the second-sector value added using the proportion of provincial government expenditure, provincial environmental expenditure, and second-sector value added as independent variables. General budget expenditure of local finance amounted to (100 million CNY). The most relevant variable is the provincial government expenditure (100 million CNY), computed by subtracting annual general provincial government expenditure when these variables were collected from the National Bureau of Statistics of China. Moreover, the study variables were mentioned below in Table 1.

Table 1 . The study variables.

\begin{tabular}{|c|c|c|c|}
\hline Variable & Definition & Mesures & Ressources \\
\hline COD & COD Emission in Waste Water & $(10,000$ tons $)$ & \multirow{9}{*}{$\begin{array}{c}\text { National Bureau of Statistics } \\
\text { of China, } 2018\end{array}$} \\
\hline NOx & Ammonia Nitrogen Emission in Waste Water & $(10,000$ tons $)$ & \\
\hline $\mathrm{SO}_{2}$ & Sulphur Dioxide Emission in Waste Gas & (10,000 tons) & \\
\hline LGE & Local government expenditure & (100 million yuan) & \\
\hline ENVE & provincial environmental expenditure & (100 million yuan) & \\
\hline GDPP & Per Capita Gross Regional Product & (yuan/person) & \\
\hline $\mathrm{GDPP}^{2}$ & Per Capita Gross Regional Product square & (yuan/person) & \\
\hline $\mathrm{GDPP}^{3}$ & Per Capita Gross Regional Product cube & (yuan/person) & \\
\hline SSVA & second-sector value added & (100 million yuan) & \\
\hline
\end{tabular}

Table 2 implicitly shows the descriptive statistics of the underlying variables. Table 2 confirms that COD release, $\mathrm{SO}_{2}$, and $\mathrm{AN}$ emissions in China have maximum values of 5.289, $10.416,3.139$, and minimum values of $0.405,-1.966,-1.388$, with an average of $3.738,7.362$, and 1.388 , respectively. This illustrates a large disparity in environmental pollutant emissions in the different provinces of China. Problematic and threatening to the environmental system in China, Table 1 also depicts the features of government outbursts when there is a large discrepancy between the minimum and maximum values and a very large standard deviation of 0.758796 , which indicates that government expenditure varies greatly across Chinese regions. However, the average value of government expenditure is 7,881,049 CNY across Chinese provinces. The record of government expenditure (ENVE) on the environment sector and the added value of the second industrial sector (SSVA) shows an average value of 4.302 and 4.698, with a minimum value of 1.562 and 4.472 , and a maximum value of 6.129 and 4.819 , respectively. This characteristic is also reflected in the record of per capita GDP with an average value of 9.336 , minimum value of 5.840, and maximum value of 11.425 . However, there is a significant 
disparity in per capita GDP in different Chinese sectors. This explains the unevenness of economic growth in various Chinese regions.

Table 2. Descriptive statistics of the study variables.

\begin{tabular}{|c|c|c|c|c|c|c|c|c|c|c|c|c|}
\hline Variables & Mean & Median & Maximum & Minimum & $\begin{array}{c}\text { Standard } \\
\text { Devia- } \\
\text { tion }\end{array}$ & Skewness & Kurtosis & $\begin{array}{c}\text { Jarque- } \\
\text { Bera }\end{array}$ & Sum & $p$-Value & $\begin{array}{l}\text { Sum of } \\
\text { Squares }\end{array}$ & Observation \\
\hline (GDPP) & 9.336 & 9.453 & 11.425 & 5.840 & 1.060 & -0.802 & 3.634 & 42.357 & 3183.777 & 0.00 & 382.672 & 341 \\
\hline (COD) & 3.738 & 3.887 & 5.289 & 0.405 & 0.942 & -0.925 & 4.015 & 63.352 & 1274.882 & 0.00 & 302.316 & 341 \\
\hline$\left(\mathrm{SO}_{2}\right)$ & 7.362 & 8.006 & 10.416 & -3.543 & 2.576 & -2.011 & 7.520 & 520.294 & 2510.695 & 0.00 & 2257.490 & 341 \\
\hline (AN) & 1.388 & 1.558 & 3.139 & -1.966 & 0.973 & -0.914 & 3.891 & 58.877 & 473.608 & 0.00 & 322.307 & 341 \\
\hline (LGE) & 7.881 & 8.028 & 9.618 & 5.488 & 0.758 & -0.640 & 3.310 & 24.683 & 2687.438 & 0.00 & 195.762 & 341 \\
\hline (ENVE) & 4.302 & 4.411 & 6.127 & 1.562 & 0.786 & -0.665 & 3.836 & 35.093 & 1467.277 & 0.002 & 210.492 & 341 \\
\hline (SSVA) & 4.698 & 4.700 & 4.819 & 4.472 & 0.051 & -0.378 & 3.498 & 11.679 & 1602.225 & 0.000 & 0.914 & 341 \\
\hline
\end{tabular}

\section{Empirical Results}

\subsection{Estimation Results and Discussion}

According to our hypothesis and the theoretical framework, an N-shaped relationship between income, when indicated by locale GDP per capita and capture of environmental degradation, should be expected in the estimations [50]. However, as seen in the Tables 2-5, the results are inconclusive between classifications and the different methods used in the Fully Modified Least Square (FMOLS), difference- The generalized method of moments (GMM). There are two stages to the estimating technique [51].

Table 3. Results for the second-stage estimation: nexus between the three pollutant emissions factors $\mathrm{SO}_{2}, \mathrm{COD}$, and AN emissions, and provincial economic growth per capita GDPP.

\begin{tabular}{|c|c|c|c|}
\hline & (FMOLS) & Difference-GMM & Orthogonal-GMM \\
\hline \multirow[t]{2}{*}{$\operatorname{Ln}(G D P P)_{(-1)}$} & & 0.681 * & 0.681 * \\
\hline & & 32.917 & 11.563 \\
\hline \multirow[t]{2}{*}{ Ln(LGE) } & $1.056^{*}$ & 0.337 * & 0.318 * \\
\hline & 11.104 & 14.197 & 6.007 \\
\hline \multirow[t]{2}{*}{ Ln(ENVE) } & $-0.145^{* * *}$ & $-0.131 *$ & $-0.103 *$ \\
\hline & -1.666 & -15.3904 & -4.409 \\
\hline \multirow[t]{2}{*}{$\mathrm{Ln}\left(\mathrm{SO}_{2}\right)$} & 0.025 & -0.020 & $-0.018 *$ \\
\hline & 1.380 & -6.536 & -3.418 \\
\hline \multirow[t]{2}{*}{$\operatorname{Ln}(\mathrm{COD})$} & 0.018 & $0.023 *$ & $0.017 *$ \\
\hline & 0.245 & 6.511 & 2.337 \\
\hline \multirow[t]{2}{*}{$\operatorname{Ln}(\mathrm{AN})$} & 0.360 * & $-0.023 *$ & -0.016 \\
\hline & 4.657 & -2.891 & -1.422 \\
\hline \multirow[t]{2}{*}{ Ln(SSVA) } & $0.183^{* * *}$ & $0.844^{*}$ & $0.696^{*}$ \\
\hline & 1.73 & 19.123 & 3.297 \\
\hline R-squared & 0.880 & & \\
\hline Adjusted R-squared & 0.878 & & \\
\hline S.E. of regression & 0.362 & & \\
\hline Long-run variance & 0.220 & & \\
\hline Root MSE & & 0.050 & 0.040 \\
\hline S.D. dependent var. & & 0.050 & 0.189 \\
\hline Sum squared resid. & & 0.708 & 0.463 \\
\hline Instrument rank & & 32 & 45 \\
\hline
\end{tabular}


Table 4. Results for the second-stage estimation using sulfur dioxide $\left(\mathrm{SO}_{2}\right)$ as the dependent variable.

\begin{tabular}{cccc}
\hline & (FMOLS) & Difference-GMM & Orthogonal-GMM \\
\hline $\mathrm{Ln}\left(\mathrm{SO}_{2}\right)_{(-1)}$ & & $1.290^{* * *}$ & $0.649^{*}$ \\
$\mathrm{Ln}(\mathrm{GDPP})$ & $-11.919^{* *}$ & 21.8341 & 0.871 \\
& -2.235 & -49.588 & $-2.375^{*}$ \\
$\mathrm{Ln}(\mathrm{GDPP})^{2}$ & $2.166^{*}$ & -14.538 & -0.752 \\
& 3.5012 & 6.107 & $0.334^{*}$ \\
$\mathrm{Ln}(\mathrm{GDPP})^{3}$ & $-0.099^{*}$ & 14.858 & 0.401 \\
& -4.109 & $-0.249^{* *}$ & $-0.027^{*}$ \\
$\mathrm{Ln}(\mathrm{LGE})$ & $-3.355^{*}$ & -15.594 & -0.517 \\
& -4.904 & $1.353^{*}$ & $2.360^{*}$ \\
Ln(ENVE) & $1.685^{*}$ & 11.222 & 3.290 \\
& 3.758 & $-0.408^{* * *}$ & $-0.372^{*}$ \\
Ln(SSVA) & $6.572^{* *}$ & -9.731 & -1.097 \\
$\mathrm{R}-$ squared & 2.144 & $3.381 *$ & 0.290 \\
Adjusted R-squared & 0.441 & 21.087 & \\
S.E. of regression & 0.382 & & \\
Long-run variance & 54.3194 & & 0.658 \\
Root MSE & 31 & & 0.610 \\
S.D. dependent var. & & 0.535 & 121.05 \\
Sum squared resid. & & 0.591 & 31 \\
Instrument rank & & 79.9968 & 32 \\
\hline
\end{tabular}

***, and ${ }^{* * *}$ are significant at $0.01,0.05$, and 0.1, respectively. Note: $\mathrm{SO}_{2}$ : Sulphur Dioxide Emission in Waste Gas LGE: Local government expenditure; ENVE: Provincial environmental expenditure; GDPP: Per Capita Gross Regional Product; GDPP²: Per Capita Gross Regional Product square; GDPP ${ }^{3}$ : Per Capita Gross Regional Product cube; SSVA: second-sector value added.

Table 5. Results for the second-stage estimation using the chemical oxygen demand (COD) as the dependent variable.

\begin{tabular}{|c|c|c|c|}
\hline & (FMOLS) & Difference-GMM & Orthogonal-GMM \\
\hline \multirow[t]{2}{*}{$\operatorname{Ln}(\mathrm{COD})_{(-1)}$} & & $0.092 *$ & $0.040 *$ \\
\hline & & 7.598 & 2.078 \\
\hline \multirow[t]{2}{*}{ Ln (GDPP) } & $-4.256^{*}$ & $-22.067^{*}$ & $-0.626^{*}$ \\
\hline & -2.615 & -9.427 & -0.822 \\
\hline \multirow[t]{2}{*}{$\operatorname{Ln}(\mathrm{GDPP})^{2}$} & $0.651 *$ & $3.047^{*}$ & $0.092^{* *}$ \\
\hline & 3.447 & 10.141 & 3.725 \\
\hline \multirow[t]{2}{*}{$\operatorname{Ln}(\mathrm{GDPP})^{3}$} & $-0.026^{*}$ & $-0.123 *$ & -0.003 \\
\hline & -3.608 & -10.044 & -4.310 \\
\hline \multirow[t]{2}{*}{$\operatorname{Ln}(\mathrm{LGE})$} & $-0.452 * *$ & $-0.812 *$ & -0.532 \\
\hline & -2.164 & -6.303 & -0.595 \\
\hline \multirow[t]{2}{*}{ Ln(ENVE) } & $0.249 * * *$ & $-0.210 *$ & 0.258 \\
\hline & 1.825 & -11.741 & -1.527 \\
\hline \multirow[t]{2}{*}{ Ln(SSVA) } & $2.361^{* *}$ & $6.224 *$ & 1.034 * \\
\hline & 2.524 & 12.453 & 6.593 \\
\hline R-squared & 0.633 & & \\
\hline Adjusted R-squared & 0.627 & & \\
\hline S.E. of regression & 0.576 & & \\
\hline Long-run variance & 0.622 & & \\
\hline Root MSE & & 0.492 & 0.400 \\
\hline S.D. dependent var & & 0.445 & 0.382 \\
\hline Sum squared resid & & 67.801 & 44.655 \\
\hline Instrument rank & & 32 & 32 \\
\hline
\end{tabular}


The first—difference GMM approach—is the benchmark and the main method used. We utilized the (FMOLS) approach to evaluate the estimations' robustness and confirm our hypothesis of the $\mathrm{N}$-shaped EKC hypothesis for the total sample, the 31 China provinces [52]. In addition, the results of the three tests demonstrated the existence of an inverse relationship in the form of an N-shaped EKC hypothesis; we further discuss the result below [53].

Table 3 presents the outcomes of the relationship between the environmental qualities measured through three pollutant emissions factors, $\mathrm{SO}_{2}, \mathrm{COD}$, and $\mathrm{AN}$ emissions, and provincial economic growth. The findings of FMOLS stated that the local government expenditure, $\mathrm{SO}_{2}, \mathrm{COD}, \mathrm{AN}$, and SSVE positively affect the GDP [54]. However, as per orthogonal-GMM and difference- $\mathrm{GMM}, \mathrm{SO}_{2}$ and $\mathrm{AN}$ reveal a negative association with GDP. Moreover, environmental expenditures indicate a negative relationship with GDP; in addition, the result of the GMM-difference test also demonstrates its significance [55]. On the other hand, the results of FMOLS, orthogonal-GMM, and difference-GMM indicates a negative relationship of ENVE with GDP having a coefficient of -0.145 , implying that one unit increase in ENVE will decrease 0.145 units of GDP.

Table 4 enumerates the findings by taking the $\mathrm{SO}_{2}$ as the dependent variable. The results of FMOLS revealed that ENVE and SSVA have a positive link with $\mathrm{SO}_{2}$ while LGE reported a negative correlation with $\mathrm{SO}_{2}$. Moreover, difference-GMM and orthogonalGMM denote the indirect impact of ENVE with $\mathrm{SO}_{2}$ emissions and the direct impact of LGE and SSVE on $\mathrm{SO}_{2}$. The study stated that an inverted $\mathrm{N}$-shaped connection exists among the $\mathrm{GDP}, \mathrm{GDP}^{2}, \mathrm{GDP}^{3}$, and $\mathrm{SO}_{2}$. The R-square and adjusted R-square value highlighted that $44.1 \%$ of the changes are due to the factors employed in this investigation. In comparison, $38.2 \%$ of changes occur due to significant factors among them.

Based on analysis of the relationship between the pollutant emissions captured by $\mathrm{SO}_{2}$, COD and AN emissions, and regional economic growth, Tables 3-6 clarify the relationship between the $\mathrm{COD}$ release, $\mathrm{SO}_{2}$, and $\mathrm{AN}$ emissions and the local government expenditure. In Table 5, we used the COD as a dependent variable when the FMOLS test indicates the significance of GDPP, GDPP 2 , GDPP 3 at $1 \%$ level, and LGE and SSVA at $5 \%$, and ENVE at $10 \%$. The FMOLS test indicates the negative relationship between local government expenditure and chemical oxygen demand COD in China's provinces, with a coefficient of $4.52 \%$. The examination indicates a positive relationship of the environmental expenditure ENVE and SSVA with COD emissions, with a coefficient of 0.249 and 2.361, respectively. In contrast, the study confirms the existence of an inverted N-shaped hypothesis by the significance of GDPP, GDPP ${ }^{2}$, and GDPP ${ }^{3}$. The difference-GMM and orthogonal-GMM test followed the previous FMOLS result that shows stationary LGE, SSVA, GDPP, GDPP2, and GDPP ${ }^{3}$ at the first level. This also confirms the existence of the inverted N-shaped hypothesis when the difference-GMM shows a negative significance of GDPP, by $22.0 \%$, and a positive significance of GDPP ${ }^{2}$, and again the GDPP ${ }^{3}$ indicated negatively on the COD release, with a coefficient of $0.1234 \%$.

Table 5 exhibits the findings of the study when ammonia nitrogen $\mathrm{AN}$ is the dependent factor. The empirical findings confirmed the existence of an inverted $\mathrm{N}$-shaped relationship between economic growth and AN. The difference-GMM and orthogonal-GMM showed that GDPP and GDPP 3 have a negative coefficient, while GDPP ${ }^{2}$ presents a positive sign. FMOLS outcomes also verify these findings. Moreover, the study indicates the negative effect of local government expenditure on the AN emissions with a coefficient of -0.40459 . The R-squared indicates that $66.4 \%$ variation in the AN occurred due to the variables used in this study. However, $65.8 \%$ changes in the AN are due to the significant variables among them. 
Table 6. Results for the second-stage estimation using ammonia nitrogen emissions (AN) as the dependent variable.

\begin{tabular}{cccc}
\hline & (FMOLS) & Difference-GMM & Orthogonal-GMM \\
\hline Ln(AN) $)_{\text {it(-1) }}$ & & $0.692^{*}$ & $0.689^{*}$ \\
Ln(GDPP) & $-5.804^{*}$ & 19.364 & 21.051 \\
& -3.924 & $-49.093^{*}$ & $-40.810^{*}$ \\
Ln(GDPP) ${ }^{2}$ & $0.823^{*}$ & -4.432 & -3.252 \\
& 4.797 & $5.588^{*}$ & $4.642^{*}$ \\
Ln(GDPP) & $-0.032^{*}$ & 4.416 & 3.331 \\
& -4.817 & $-0.215^{*}$ & $-0.179 *$ \\
Ln(LGE) & $-0.404^{*}$ & -4.564 & -3.521 \\
& -2.131 & $2.415^{*}$ & $2.483^{*}$ \\
Ln(ENVE) & $0.023^{*}$ & 6.472 & -0.288 \\
& 0.187 & $-0.916^{*}$ & -6.920 \\
Ln(SSVA) & $2.845^{*}$ & -6.485 & $9.337 *$ \\
R-squared & 3.347 & $8.882^{*}$ & 8.549 \\
Adjusted R-squared & 0.664 & 12.200 & \\
S.E. of regression & 0.658 & & \\
Long-run variance & 0.569 & & 0.459 \\
Root MSE & 0.514 & & 0.420 \\
S.D. dependent var. & & 0.459 & 38.871 \\
Sum squared resid. & & 0.373 & 39.027 \\
Instrument rank & & 31 & \\
\hline
\end{tabular}

* is significant at 0.01. Note: AN: Ammonia Nitrogen Emission in Waste Water; LGE: Local government expenditure; ENVE: Provincial environmental expenditure; GDPP: Per Capita Gross Regional Product; GDPP2: Per Capita Gross Regional Product square; GDPP ${ }^{3}$ : Per Capita Gross Regional Product cube; SSVA: Second-sector value added.

\subsection{Discussing the Results of the Study}

Based on Tables 2-6, the econometric results show consistent findings for any classification regarding the association between economic growth per capita and environmental degradation [56]. Although the FMOLS test showed an N-shaped EKC hypothesis for the capture of pollution nexus between the three pollutant emissions factors (COD release, $\mathrm{SO}_{2}$, and AN emissions) and provincial economic growth in the Chinese provinces, only a few quantiles confirm these results [53]. These inconclusive findings could depend on the heterogeneity between and within these revenue groups. A further breakdown of the provinces included and their specific characteristics, such as local development, the composition of industries, and local environmental laws, might be needed to fully understand why the N-shaped EKC is only apparent in some quantiles [57]. The current study was not presented in a way similar to the previous studies, by dividing the Chinese provinces into groups to avoid statistical problems and the small size of the sample. The first finding is an inverted N-shaped relationship between pollution variables and China's province per capita income [58]. As per capita wealth rises, pollution variables decrease at first, then increase, and then decrease. As the economy progresses, the marginal advantage of regionally sound environmental quality has gradually increased [59]. By introducing rules and regulations to compensate for market failure, the government will respond to public demand for a clean environment and prevent pollution from increasing. As per capita income grows in the first stage, then pollution factors decrease as a result. New types of pollution will arise due to economic expansion, and existing market mechanisms and environmental regulations may not effectively mitigate these new types of pollution [26]. When the government has sufficient pollution data and uses cleaner manufacturing technologies, then it will set higher environmental standards and enforce stricter environmental rules [60]. The second turning point of the inverted N-shaped curve will occur simultaneously; the quality of the regional sound environment will improve even though both the FMOLS and the GMM estimations show an inverted N-shape [61]. 


\section{Conclusions and Implications}

The current study sheds light on the role that government spending generally played and local government spending specifically played in protecting the environment and improving environmental quality in 31 Chinese provinces between 2007 and 2017. It examines the nature of the relationship and the extent of the impact of local government spending on three variables that were chosen to measure the extent of pollution-COD release, $\mathrm{SO}_{2}$, and $\mathrm{AN}$ emissions - combining the contribution of both local economic growth and value added by the second sector, which measures the industrial strength of the Chinese provinces. Moreover, due to the nature of the data available, both the economic model FMOLS and GMM are applied. This study explores the nature of the relationship between the study variables, ensuring the EKC hypothesis. However, the study results agreed with the study's objectives and hypotheses, as the analysis results show that the EKC hypothesis is fulfilled. In each of the first, second, and third models, an inverted relationship is identified between environmental degradation, $\mathrm{COD}$ release, $\mathrm{SO}_{2}, \mathrm{AN}$, and economic growth in 31 provinces of China.

However, the study indicates that government expenditure is one of the determinants of pollution in China, including the local government expenditure on the protection of the environment. The econometric results reveal a negative connection between the capture pollution and GDPP, a positive relationship with GDPP ${ }^{2}$, and a negative relationship with GDPP ${ }^{3}$. According to the GMM test, we find a negative relationship between the government expenditure and capture of pollution. However, GDPP on environmental quality affected the local government expenditure indirectly.

Additionally, the GDPP, $\mathrm{COD}$ release, $\mathrm{SO}_{2}$, $\mathrm{AN}$ emissions decrease substantially, but at various rates and times. This paper has elucidated future studies in this field to explore the link between government expenditure and environmental quality in China using rigorous econometric approaches and splitting the overall effect into direct and indirect impacts. Several straightforward policy implications that may be inferred from these findings follow. For example, two components of government expenditure on environmental quality may be investigated further. Government expenditures on education, research and development (R\&D), and infrastructure investment, for example, may all have an impact on the environment. Because $\mathrm{SO}_{2}$ emissions negatively influence people's health, the government improved air quality previously. In contrast, COD release is not taken as seriously. As a result, recent years have seen an increase in emissions. Increased government spending can significantly minimize $\mathrm{COD}$ release and $\mathrm{SO}_{2}$ and $\mathrm{AN}$ emissions since a larger ratio of government expenditure decreases pollution emissions.

Based on the conclusions and preliminary results, we can give the following recommendation first: increase attention on the local environmental system of the Chinese provinces and work toward designing a system that balances local economic growth and environmental preservation. It is also necessary to work on managing local regulations and laws to cover various local environmental dimensions and sustainability, such as gaseous and industrial emissions and water pollution resulting from sewage. Second: work on building a local government spending system on foundations based on governance and monitoring the independence of government spending for local districts, which would maximize the volume of environmental conservation and reduce emissions. Third: improve the industrial structure and accelerate the transformation of the local industrial structure into an environment-friendly system. Although secondary industry was a significant growth engine for China's economy, it caused growth of environmental pollution, which requires the intervention of the Chinese government to develop the industrial sector and achieve sustainable environmental development goals. Fourth: decision-makers should build strategies to preserve the environmental system on the most basic assumptions that keep pace with the size of the Chinese economy and the environmental challenges it faces, such as the Keynesian hypotheses. These depend on the cube of economic growth, and predict the existence of a hypothesis for the existence of a third stage, which allows for a return of the parallel between economic growth and environmental pollution, resulting in an 
inverted N-shaped relationship. This is in contrast to the classical EKC hypothesis, which stops at squaring the volume of economic growth, and explains the inverse relationship between economic growth and the importance of pollution, giving an inverted U-shaped relationship. This study encountered some limitations and provides guidelines for future research: (1) this study is limited to 31 Chinese provinces that have experienced further economic growth. (2) This study uses data from 2007 to 2017; the period for future studies can be extended by later studies. (3) In addition, future studies could also include an interactive term for energetic innovation and public investments in the environment. (4) Finally, the role of renewable energies and the governance criterion can also be covered in future studies.

Author Contributions: A.Z.: data curation, writing-original draft preparation, software, and formal analysis. D.B.-L.: supervision, conceptualization, and methodology. K.S.: writing-reviewing and editing. All authors have read and agreed to the published version of the manuscript.

Funding: This research has received no external funding.

Institutional Review Board Statement: Not applicable.

Informed Consent Statement: Not applicable.

Data Availability Statement: The data presented in this study are openly available in https://data. stats.gov.cn.

Conflicts of Interest: The authors declare no conflict of interest.

\section{References}

1. China Increasing Investment in Environmental Protection. Available online: http:/ / europe.chinadaily.com.cn/business/2015-0 8/13/content_21589192 (accessed on 10 August 2021).

2. 2020 World Air Quality Report reveals Substantial Air Quality Changes. Available online: https://www.iqair.com/blog/pressreleases / covid-19-reduces-air-pollution-in-most-countries (accessed on 16 March 2021).

3. Wang, S.; Zhou, D.; Zhou, P.; Wang, Q. $\mathrm{CO}_{2}$ emissions, energy consumption and economic growth in China: A panel data analysis. Energy Policy 2011, 39, 4870-4875. [CrossRef]

4. Yu, Y.; Du, Y. Impact of technological innovation on $\mathrm{CO}_{2}$ emissions and emissions trend prediction on 'New Normal' economy in China. Atmos. Pollut. Res. 2019, 10, 152-161. [CrossRef]

5. Liang, Q.-M.; Deng, H.-M.; Liu, M. Co-control of $\mathrm{CO}_{2}$ emissions and local pollutants in China: The perspective of adjusting final use behaviors. J. Clean. Prod. 2016, 131, 198-208. [CrossRef]

6. Fan, J.-L.; Zhang, Y.-J.; Wang, B. The impact of urbanization on residential energy consumption in China: An aggregated and disaggregated analysis. Renew. Sustain. Energy Rev. 2017, 75, 220-233. [CrossRef]

7. Halkos, G.; Paizanos, E.A. The effect of government expenditure on the environment: An empirical investigation. Ecol. Econ. 2013, 91, 48-56. [CrossRef]

8. Hao, Y.; Chen, H.; Zhang, Q. Will income inequality affect environmental quality? Analysis based on China's provincial panel data. Ecol. Indic. 2016, 67, 533-542. [CrossRef]

9. Omri, A.; Daly, S.; Rault, C.; Chaibi, A. Financial development, environmental quality, trade and economic growth: What causes what in MENA countries. Energy Econ. 2015, 48, 242-252. [CrossRef]

10. Zhang, Y.-J.; Peng, Y.-L.; Ma, C.-Q.; Shen, B. Can environmental innovation facilitate carbon emissions reduction? Evidence from China. Energy Policy 2017, 100, 18-28. [CrossRef]

11. López, R.; Palacios, A. Why has Europe Become Environmentally Cleaner? Decomposing the Roles of Fiscal, Trade and Environmental Policies. Environ. Resour. Econ. 2013, 58, 91-108. [CrossRef]

12. Zhang, Q.; Zhang, S.; Ding, Z.; Hao, Y. Does government expenditure affect environmental quality? Empirical evidence using Chinese city-level data. J. Clean. Prod. 2017, 161, 143-152. [CrossRef]

13. Chen, C.-W.; Ju, Y.-R.; Chen, C.-F.; Dong, C.-D. Evaluation of organic pollution and eutrophication status of Kaohsiung Harbor, Taiwan. Int. Biodeterior. Biodegrad. 2016, 113, 318-324. [CrossRef]

14. De-La-Ossa-Carretero, J.A.; Del-Pilar-Ruso, Y.; Casalduero, F.G.; Sánchez-Lizaso, J.L. Monitoring the effects of wastewater treatment strategies. Environ. Monit. Assess. 2016, 188, 1-11. [CrossRef]

15. Hassan, S.T.; Xia, E.; Khan, N.H.; Shah, S.M.A. Economic growth, natural resources, and ecological footprints: Evidence from Pakistan. Environ. Sci. Pollut. Res. 2019, 26, 2929-2938. [CrossRef]

16. Zeng, S.; Gao, L.; Shen, R.; Ma, Y.; Li, H. Fiscal Decentralization, Pollution and China's Tourism Revenue. Sustainability 2020, 12, 1925. [CrossRef]

17. Zheng, J.; Mi, Z.; Coffman, D.; Milcheva, S.; Shan, Y.; Guan, D.; Wang, S. Regional development and carbon emissions in China. Energy Econ. 2019, 81, 25-36. [CrossRef] 
18. Shehzad, K.; Xiaoxing, L.; Sarfraz, M. Envisaging the asymmetrical association among FDI, ICT, and climate change: A case from developing country. Carbon Manag. 2021, 12, 123-137. [CrossRef]

19. Zeraibi, A.; Balsalobre-Lorente, D.; Shehzad, K. Examining the Asymmetric Nexus between Energy Consumption, Technological Innovation, and Economic Growth; Does Energy Consumption and Technology Boost Economic Development? Sustainability 2020, 12, 8867. [CrossRef]

20. Sun, J.; Wang, J.; Wang, T.; Zhang, T. Urbanization, economic growth, and environmental pollution: Partial differential analysis based on the spatial Durbin model. Manag. Environ. Qual. Int. J. 2019, 30, 483-494. [CrossRef]

21. Muhammad, S.; Long, X.; Salman, M.; Dauda, L. Effect of urbanization and international trade on CO2 emissions across 65 belt and road initiative countries. Energy 2020, 196, 117102. [CrossRef]

22. Amri, F. Carbon dioxide emissions, output, and energy consumption categories in Algeria. Environ. Sci. Pollut. Res. 2017, 24, 14567-14578. [CrossRef]

23. Grossman, G.M.; Krueger, A.B. Environmental Impacts of a North American Free Trade Agreement, NBER Working Papers Series, National Bureau of Economic Research: Cambridge, MA, USA, 1991. [CrossRef]

24. Huang, J.-T. Sulfur dioxide $\left(\mathrm{SO}_{2}\right)$ emissions and government spending on environmental protection in China-Evidence from spatial econometric analysis. J. Clean. Prod. 2018, 175, 431-441. [CrossRef]

25. Hao, Y.; Wu, Y.; Wu, H.; Ren, S. How do FDI and technical innovation affect environmental quality? Evidence from China. Environ. Sci. Pollut. Res. 2019, 27, 7835-7850. [CrossRef]

26. Xu, C.; Yiwen, Z.; Cheng, B.; Li, L.; Zhang, M. Study on environmental Kuznets Curve for noise pollution: A case of 111 Chinese cities. Sustain. Cities Soc. 2020, 63, 102493. [CrossRef]

27. Hao, Y.; Chen, Y.-F.; Liao, H.; Wei, Y.-M. China's fiscal decentralization and environmental quality: Theory and an empirical study. Environ. Dev. Econ. 2020, 25, 159-181. [CrossRef]

28. Jiang, L.; Zhou, H.; He, S. The role of governments in mitigating $\mathrm{SO}_{2}$ pollution in China: A perspective of fiscal expenditure. Environ. Sci. Pollut. Res. 2020, 27, 33951-33964. [CrossRef] [PubMed]

29. Canavire-Bacarreza, G.; Martinez-Vazquez, J.; Yedgenov, B. Identifying and disentangling the impact of fiscal decentralization on economic growth. World Dev. 2020, 127, 104742. [CrossRef]

30. Ekeocha, D.O. Urbanization, inequality, economic development and ecological footprint: Searching for turning points and regional homogeneity in Africa. J. Clean. Prod. 2021, 291, 125244. [CrossRef]

31. Elheddad, M.; Djellouli, N.; Tiwari, A.K.; Hammoudeh, S. The relationship between energy consumption and fiscal decentralization and the importance of urbanization: Evidence from Chinese provinces. J. Environ. Manag. 2020, 264, 110474. [CrossRef]

32. Zeng, S.; Zhou, Y. Foreign Direct Investment's Impact on China's Economic Growth, Technological Innovation and Pollution. Int. J. Environ. Res. Public Health 2021, 18, 2839. [CrossRef]

33. Yuelan, P.; Akbar, M.W.; Hafeez, M.; Ahmad, M.; Zia, Z.; Ullah, S. The nexus of fiscal policy instruments and environmental degradation in China. Environ. Sci. Pollut. Res. 2019, 26, 28919-28932. [CrossRef]

34. Hao, Y.; Zheng, S.; Zhao, M.; Wu, H.; Guo, Y.; Li, Y. Reexamining the relationships among urbanization, industrial structure, and environmental pollution in China-New evidence using the dynamic threshold panel model. Energy Rep. 2020, 6, 28-39. [CrossRef]

35. Ullah, S.; Ozturk, I.; Sohail, S. The asymmetric effects of fiscal and monetary policy instruments on Pakistan's environmental pollution. Environ. Sci. Pollut. Res. 2021, 28,7450-7461. [CrossRef]

36. Basoglu, A.; Uzar, U. An empirical evaluation about the effects of environmental expenditures on environmental quality in coordinated market economies. Environ. Sci. Pollut. Res. 2019, 26, 23108-23118. [CrossRef]

37. Halkos, G.E.; Paizanos, E.A. The channels of the effect of government expenditure on the environment: Evidence using dynamic panel data. J. Environ. Plan. Manag. 2016, 60, 135-157. [CrossRef]

38. Luo, G.; Weng, J.-H.; Zhang, Q.; Hao, Y. A reexamination of the existence of environmental Kuznets curve for $\mathrm{CO}_{2}$ emissions: Evidence from G20 countries. Nat. Hazards 2017, 85, 1023-1042. [CrossRef]

39. Arellano, M.; Bond, S. Some Tests of Specification for Panel Data: Monte Carlo Evidence and an Application to Employment Equations. Rev. Econ. Stud. 1991, 58, 277. [CrossRef]

40. Blundell, R.; Bond, S. Initial conditions and moment restrictions in dynamic panel data models. J. Econom. 1998, 87, 115-143. [CrossRef]

41. Hao, Y.; Zhang, Z.-Y.; Liao, H.; Wei, Y.-M.; Wang, S. Is $\mathrm{CO}_{2}$ emission a side effect of financial development? An empirical analysis for China. Environ. Sci. Pollut. Res. 2016, 23, 21041-21057. [CrossRef]

42. Phillips, R.F. A Comparison of First-Difference and Forward Orthogonal Deviations GMM. 2019, pp. 1-13. Available online: http:/ / arxiv.org/abs/1907.12880 (accessed on 10 July 2021).

43. Fan, W.; Li, L.; Wang, F.; Li, D. Driving factors of $\mathrm{CO}_{2}$ emission inequality in China: The role of government expenditure. China Econ. Rev. 2020, 64. [CrossRef]

44. Hansen, B.E. Testing for Parameter Instability in Linear Models. J. Policy Model. 1992, 14, 517-533. [CrossRef]

45. Aljadani, A.; Toumi, H.; Toumi, S.; Hsini, M.; Jallali, B. Investigation of the N-shaped environmental Kuznets curve for COVID-19 mitigation in the KSA. Environ. Sci. Pollut. Res. 2021. [CrossRef] [PubMed]

46. Twerefou, D.K.; Danso-Mensah, K.; Bokpin, G.A. The environmental effects of economic growth and globalization in Sub-Sharan Africa: A panel general method of moments approach. Res. Int. Bus. Financ. 2017, 42, 939-949. [CrossRef] 
47. Junaidi, J.; Jamal, A.; Syahnur, S. Sukuk and Endogenous Growth in Indonesia: Generalized Method of Moments Approach. Adv. Soc. Sci. Educ. Humanit. Res. 2019, 292, 633-639. [CrossRef]

48. López, R.; Galinato, G.I.; Islam, A. Fiscal spending and the environment: Theory and empirics. J. Environ. Econ. Manag. 2011, 62, 180-198. [CrossRef]

49. Zhou, K.; Zhou, B.; Yu, M. The impacts of fiscal decentralization on environmental innovation in China. Growth Change 2020, 51, 1690-1710. [CrossRef]

50. Nathaniel, S.P. Ecological footprint, energy use, trade, and urbanization linkage in Indonesia. GeoJournal 2020, 7, 1-14. [CrossRef]

51. Gu, C.; Xie, H.; Lu, X.; Zhang, C. CGMVAE: Coupling GMM Prior and GMM Estimator for Unsupervised Clustering and Disentanglement. IEEE Access 2021, 9, 65140-65149. [CrossRef]

52. Zhang, J. Environmental Kuznets Curve Hypothesis on CO2 Emissions: Evidence for China. J. Risk Financ. Manag. 2021, 14, 93. [CrossRef]

53. Pal, D.; Mitra, S.K. The environmental Kuznets curve for carbon dioxide in India and China: Growth and pollution at crossroad. J. Policy Model. 2017, 39, 371-385. [CrossRef]

54. Lan, H.; Hart, C.A.; Yujia, M.; Kovacic, Z.J. Fiscal Decentralization, Environmental Accountability and the Provision of Environmental Public Goods in China: Evidence from 30 Provinces. SSRN Electron. J. 2014, 1-26. [CrossRef]

55. Zheng, W.; Walsh, P.P. Economic growth, urbanization and energy consumption-A provincial level analysis of China. Energy Econ. 2019, 80, 153-162. [CrossRef]

56. Aydin, C.; Esen, Ö.; Aydin, R. Is the ecological footprint related to the Kuznets curve a real process or rationalizing the ecological consequences of the affluence? Evidence from PSTR approach. Ecol. Indic. 2019, 98, 543-555. [CrossRef]

57. Cheng, S.; Fan, W.; Chen, J.; Meng, F.; Liu, G.; Song, M.; Yang, Z. The impact of fiscal decentralization on $\mathrm{CO}_{2}$ emissions in China. Energy 2020, 192. [CrossRef]

58. Sinha, A.; Shahbaz, M.; Balsalobre, D. Exploring the relationship between energy usage segregation and environmental degradation in N-11 countries. J. Clean. Prod. 2017, 168, 1217-1229. [CrossRef]

59. Ali, H.S.; Law, S.H.; Lin, W.L.; Yusop, Z.; Chin, L.; Bare UA, A. Financial development and carbon dioxide emissions in Nigeria: Evidence from the ARDL bounds approach. GeoJournal 2019, 84, 641-655. [CrossRef]

60. Ahmed, Z.; Asghar, M.M.; Malik, M.N.; Nawaz, K. Moving towards a sustainable environment: The dynamic linkage between natural resources, human capital, urbanization, economic growth, and ecological footprint in China. Resour. Policy 2020, 67, 101677. [CrossRef]

61. Lu, C.; Venevsky, S.; Shi, X.; Wang, L.; Wright, J.S.; Wu, C. Econometrics of the environmental Kuznets curve: Testing advancement to carbon intensity-oriented sustainability for eight economic zones in China. J. Clean. Prod. 2021, 283, 124561. [CrossRef] 